\title{
Roles of rural and remote registered nurses in Australia: an integrative review
}

\section{AUTHORS}

SUSAN MUIRHEAD RN RM MN ${ }^{1}$

MELANIE BIRKS RN PhD²
1. Rural and Remote Clinical Support Unit, Queensland Health. Cairns, Australia.

2. Nursing and Midwifery, College of Healthcare Sciences, James Cook University. Townsville, Australia.

\section{CORRESPONDING AUTHOR}

SUSAN MUIRHEAD, Rural and Remote Clinical Support Unit, Queensland Health. Cairns, QLD, Australia. 4870. Phone: +61 431606 313. Email: susan.muirhead@my.jcu.edu.au

\section{ABSTRACT}

Objective: The aim of this review is to explore the multifaceted roles of registered nursing practice in rural and remote areas of Australia.

Background: People in rural and remote Australia have less access to healthcare than their metropolitan counterparts. They are also burdened with higher rates of chronic disease and premature mortality. These areas also have less doctors and allied health professionals than metropolitan areas, with the core workforce being registered nurses. One strategy to address the health workforce disparities, is to promote registered nurses to work to their full scope and in advanced generalist roles. An understanding of the current roles of the registered nurse is therefore required to assist in determining how their scope could be extended, and to inform appropriate educational planning.

Study design and methods: An integrative review of literature was used to obtain articles from online databases relevant to nursing from 1995 to 2017. Data was quality appraised, extracted, and thematically analysed.

Results: Registered nurses in rural and remote Australia work in diverse contexts that have a major influence on the roles they undertake. They are already required to be multi-skilled and to practice at an advanced level, including undertaking some aspects of the health professional role traditionally the domain of medical practitioners. These registered nurses often feel unprepared for the breadth and complexity of this role.

Discussion: To enable registered nurses to be adequately prepared for rural and remote practice, educational programs need to be flexible, accessible and affordable. The registered nurse's existing experience and expertise should be recognised, and educational pathways structured to enable the nurse to expand their practice according to the context in which they work and the needs of the community.

Conclusion: Registered nurses in rural and remote areas function as advanced generalists. Greater understanding of these roles is necessary to inform the development of 'fit for purpose' educational models.

Implications for research, policy and practice: Future research is needed to focus on evaluation of existing models of rural and remote nursing practice and in particular the role of the nurse as doctor substitute. The findings of this study highlight the potential expanded contribution of registered nurses in these areas, which is an important factor for consideration by policy makers. In practice, supportive frameworks are required to ensure registered nurses are able to function to their full capacity in their unique context. 
Key words: Educational models, rural nursing, nurse role, remote area nurse

What is already known about the topic?

People living in rural and remote areas are subjected to inequities in respect of health and access to healthcare services

Registered nurses working in rural and remote areas are essential for addressing healthcare needs that would otherwise be unmet

Nurses practicing in these areas require an advanced skills-set in order to function effectively in their role

\section{What this paper adds}

This paper examines the multifaceted role of the registered nurse working in rural and remote areas of Australia as described in the literature

Four main themes were identified: roles shaped by context; doctor substitute; multi-skilled and advanced practice; and feeling unprepared

Understanding the complexity of the registered nurse role in rural and remote areas enables the development of policy, practice and educational approaches to support nurses in functioning to their full capacity

\section{INTRODUCTION}

Approximately $30 \%$ of the Australian population live outside of metropolitan areas, with $11 \%$ living in outer regional, remote or very remote areas. ${ }^{1}$ Additionally, a large proportion of Aboriginal and Torres Strait Islander people (Australia's Indigenous population) live in remote areas (21\%) and comprise around $45 \%$ of the population living in very remote Australia. ${ }^{2}$

The health of rural and remote people in Australia is poorer than those residing in major cities, with higher rates of chronic disease, injury and premature mortality. ${ }^{3}$ Furthermore, as the distance from cities and regional areas increases, so to do disease risk factors and levels of illness. ${ }^{4}$ The poorer health and reduced life expectancy of Aboriginal and Torres Strait Islander people, as compared to nonIndigenous people, is well established, ${ }^{3}$ with their health status also deteriorating the more remotely they live. ${ }^{2}$

In addition to having poorer health, rural and remote people have less access to healthcare than their city counterparts. ${ }^{3}$ Health services in rural and remote areas have smaller facilities, less infrastructure, less access to specialist services, and are tasked with delivering services to a diverse population. ${ }^{4}$ Furthermore, these areas have less doctors and allied health staff than metropolitan areas and experience a higher turnover of registered nurses (RNs). ${ }^{5}$

The Australian Government acknowledges the health disparities of rural and remote people, and a primary goal of the 'National Strategic Framework for Rural and Remote Health', ${ }^{4}$ is for equal access to healthcare for everyone, regardless of the geographical location. This goal includes access to an "appropriate, skilled and well supported health workforce". $4(\mathrm{np})$ To build an appropriate workforce, an objective of the Framework includes exploring flexibility in the scope of practice of health professionals, improved access to training and continuing professional development, and promotion of advanced skill roles for nurses and general practitioners. ${ }^{4}$ Consistent with this objective, the review presented in this paper promotes greater understanding the roles of rural and remote RNs undertake. This understanding will inform the development of 'fit for purpose' educational models.

Queensland, a state which boasts a significant proportion of the rural and remote population in Australia, ${ }^{1}$ sees 'rural generalist' health professionals as being central for sustainability and capability of rural and remote healthcare. ${ }^{6}$ In their 2017-20 workforce strategy, the Queensland Government proposed a structured 'fit for purpose' rural and remote (generalist) model for RNs be developed, enabling them to practice to their full (and expanded) scope within appropriate clinical governance arrangements. ${ }^{6}$

One initiative to address workforce capability in rural and remote areas in Australia, is the rural and isolated practice registered nurse (RIPRN) qualification. The RIPRN qualification equips RNs with skills in assessment and diagnosis relevant to rural and remote primary care. RIPRN qualified RNs are authorised by state or territory legislation to initiate medicines, such as antimicrobials and immunisations, a process supported by context specific clinical guidelines. ${ }^{7}$ The RIPRN qualification, however, only encompasses some facets of the rural and remote RN's role. It is therefore timely to consider the unique needs of rural and remote communities and how RNs working in these areas contribute to meeting these needs.

\section{METHOD}

\section{AIMS}

This review aims to examine the multifaceted role of the RN working in rural and remote areas of Australia as described in the literature. Consideration will be given as to how appropriate preparation for the role can be ensured. The review question is 'What are the roles of rural and remote registered nurses in the Australian context?' 


\section{DESIGN}

An integrative review methodology was used to allow for inclusion of diverse methodologies, theoretical and empirical literature. ${ }^{8}$ This method was selected over other review methods as early searches indicated practice literature and qualitative studies were most prominent in the topic. Prior to conducting the review, planning was performed based on the principles of the PRISMA-P-2015 checklist. ${ }^{9}$ An a priori protocol was not developed. The review process involved retrieval of relevant literature using a transparent and reproducible search methodology; assessment of quality using a structured critical appraisal process; and the resulting data analysed and synthesised. ${ }^{10}$

\section{SEARCH METHODS}

Online databases relevant to nursing and healthcare were searched. These included CINAHL, Scopus, Medline (Ovid), Informit Health Databases, PsycINFO (ProQuest), Joanna Briggs Institute (Ovid) and Cochrane Library. Trove was searched for Australian Masters and PhD dissertations/theses, and the educational databases ERIC (Education Resources Information Centre, [ProQuest]) and Informit A+ Education were perused for educational studies related to the topic.

Key search words included: rural, remote, registered nurses, Australia and roles. Alternate key words, Boolean terms (AND and OR), subject heading suggestions and MeSH terms were used to broaden or narrow the search as required. Appendix A (see Supplementary Material) provides an example of the search strategy performed for Scopus.

Search limits included the English language, full text, and dating from 1995 to 2017. Preliminary searches identified a seminal review by Hegney that is frequently cited in more recent literature and therefore older papers were considered worthwhile exploring. ${ }^{11}$ Reference lists of relevant articles were also hand searched for additional papers that may have been missed in the database searches. The final search was performed in October 2017.

During the search process, each article was assessed against predetermined inclusion and exclusion criteria as presented in Box 1. Slight modifications were made to these criteria as the search evolved. Community and practice nursing were excluded to ensure the review was focused on roles rather than areas or specialisations of nursing. Practice literature was added as several practice literature papers relevant to the review question were located during the search, while there were limited research papers. Practice literature are published non-research articles "written by practitioners about their field of expertise" and could include (for example) “expert opinion, discussion papers, debate, (and) ethical arguments". ${ }^{2(\mathrm{p} 45)}$

\begin{tabular}{l|l|}
\hline Inclusion criteria & Exclusion criteria \\
\hline Registered nurses & $\begin{array}{l}\text { Nurse practitioner } \\
\text { Enrolled nurse } \\
\text { Rural and remote }\end{array}$ \\
$\begin{array}{l}\text { Australia } \\
\text { Qualitative, quantitative } \\
\text { and mixed method }\end{array}$ & $\begin{array}{l}\text { Community nursing } \\
\text { Other professions/people } \\
\text { research methodology }\end{array}$ \\
$\begin{array}{l}\text { (e.g. doctors, health workers, allied } \\
\text { health, farmers) }\end{array}$ \\
$\begin{array}{l}\text { Other aspects of rural and remote } \\
\text { nursing not related to roles } \\
\text { (e.g. stress) } \\
\text { Countries other than Australia } \\
\text { (e.g. Canada) } \\
\text { Grey literature }\end{array}$ \\
\hline
\end{tabular}

\section{BOX 1: INCLUSION AND EXCLUSION CRITERIA}

Endnote was used for record keeping of each database search result and as a repository for articles found. This program was also used to facilitate removal of duplicate publications.

\section{SEARCH OUTCOMES}

A total of 496 articles were retrieved from the online database search, and a further 19 through hand searching reference lists. The database retrieved articles were initially reviewed for relevance by title only, resulting in 445 being excluded. Duplicates were removed from the 70 remaining articles, leaving 51. These were reviewed by title and abstract against the inclusion and exclusion criteria, resulting in an additional 14 being excluded. The full text of the remaining 37 articles were reviewed and 19 were excluded due to not meeting inclusion criteria. Of the excluded articles, three were literature reviews related to the roles of rural and remote RNs. ${ }^{13-15}$ These were examined to ensure that this review was not duplicating work already published. Two articles which met the inclusion criteria were excluded one as it was a duplication of a research study by the same author, ${ }^{16}$ and another as only an incomplete version of the article was accessible. ${ }^{17}$

\section{QUALITY APPRAISAL}

Fit for purpose tools were used to complete a comprehensive systematic appraisal of the remaining 16 papers. ${ }^{12}$ The Critical Appraisal Skills Programme (CASP) qualitative checklist, as suggested by the Cochrane Collaboration, ${ }^{18}$ was used to analyse the qualitative research studies. The AACODS (Authority, Accuracy, Coverage, Objectivity, Date, Significance) checklist, a generic appraisal tool developed by Tyndall, ${ }^{19}$ was used for the practice literature.

Two articles were excluded during the quality appraisal process. Rosenberg and Canning was removed due to low quality (a lack of clarity in the research aim, research methodology and rationale for recruitment of participants; no discussion of ethics approval, the consent process or anonymity; and thematic analysis and themes extracted from qualitative data not clearly described).${ }^{20}$ A paper by Bagg was 
excluded as it was limited to the experience and views of a single person, and the credibility and qualifications of the author could not be established. ${ }^{21}$

Of the remaining 14 papers, eight were qualitative research articles. Through appraisal using CASP, it was determined all had clear aims and used qualitative research methodology appropriately to meet the objectives of the research. Five were assessed as having an appropriate recruitment strategy. Of the other three, the recruitment strategy was unclear, ${ }^{22}$ had a limited description, ${ }^{23}$ or the justification did not appear to meet the aims of the research. ${ }^{24}$ Seven studies described appropriate data collection for the study design, and one was limited in the description. ${ }^{24}$ The relationship between the researcher and participants was unclear in most papers, with only three addressing reflexivity appropriately. ${ }^{25-27}$ This omission may have resulted in a bias in the studies, and therefore reduced the reliability of the study outcomes. Six studies included a thorough description of ethical issues, with the remaining two only providing a moderate description. ${ }^{27,28}$
All studies described rigorous data analysis, provided clear statements of findings, and articulated value of the research. They were therefore deemed of satisfactory quality to include in the review, with appropriate rigor applied in particular to methodology and analysis of data. Appraisal of the remaining six practice literature papers using the AACODS tool resulted all being considered of adequate quality for inclusion in the review. A summary of the appraisal of the research articles included in the review is presented in Appendix B and practice literature in Appendix C (see Supplementary Material). A total of 14 articles were therefore included in the literature review, comprising eight research studies, and six practice literature papers. A summary of these papers is presented in Table 1.

The Preferred Reporting Items for Systematic reviews and Meta-Analyses (PRISMA) flow chart has been used to illustrate transparency of the search processes, ${ }^{29}$ (Figure 1 ). The lead author performed the search and quality appraisal of the papers.

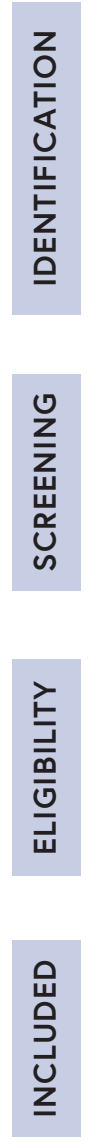

\section{Records identified through database} searching $(n=496)$

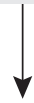

Records screened by title and discarded $(n=445)$

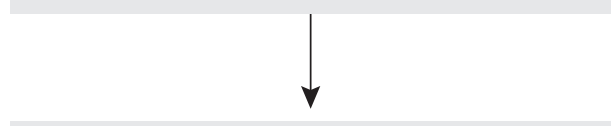

Records remaining $(\mathrm{n}=70)$

Duplicates removed $(n=19)$

Reviewed by title and abstract $(n=51)$

Full-text articles assessed for eligibility (relevance and critical appraisal) $(n=37)$

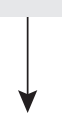

Articles to be included $(n=14)$

Research studies $(n=8)$

Practice literature $(n=6)$
Additional records identified through hand searching reference lists $(n=19)$

FIGURE 1: PRISMA FLOW DIAGRAM

Full-text articles excluded $(n=23)$

Reasons

- do not meet inclusion criteria $(n=19)$

- duplication of another paper by same author $(n=1)$

- questionable quality $(n=2)$

- unable to locate full article $(n=1)$ 
TABLE 1: SUMMARY OF INCLUDED ARTICLES

\begin{tabular}{|c|c|c|c|c|c|c|}
\hline Study & Title & Setting/context & Method & Sample & Main findings (summary) & $\begin{array}{l}\text { Comments/ } \\
\text { recommendations }\end{array}$ \\
\hline \multicolumn{7}{|c|}{ Research literature } \\
\hline $\begin{array}{l}\text { Al-Motlaq, } \\
\text { Mills, Birks, } \\
\text { and Francis } \\
(2010)\end{array}$ & $\begin{array}{l}\text { How nurses address the } \\
\text { burden of disease in } \\
\text { remote or isolated areas in } \\
\text { Queensland (Qld) }\end{array}$ & $\begin{array}{l}\text { Remote and isolated } \\
\text { Queensland } \\
\text { No Medical Officer (MO) } \\
\text { on site }\end{array}$ & $\begin{array}{l}\text { Multiple case study - } \\
\text { interviews, focus groups } \\
\text { Part of a larger study of } \\
\text { role of nurses working in } \\
\text { remote or isolated areas } \\
\text { of Qld }\end{array}$ & $\begin{array}{l}35 \text { Registered nurses } \\
\text { (RNs) }\end{array}$ & $\begin{array}{l}\text { Role varies according to place of practice } \\
\text { Felt underprepared/time poor for primary } \\
\text { healthcare - focused on emergency/acute care } \\
\text { RNs deal with chronic disease, mental health, } \\
\text { dental problems, infections, accidents, trauma, } \\
\text { abuse disorders }\end{array}$ & $\begin{array}{l}\text { Require a paradigm shift to } \\
\text { promote stronger primary } \\
\text { healthcare approach to } \\
\text { practice }\end{array}$ \\
\hline $\begin{array}{l}\text { Birks et al. } \\
(2010)\end{array}$ & $\begin{array}{l}\text { Models of healthcare } \\
\text { delivery in remote or } \\
\text { isolated Qld }\end{array}$ & $\begin{array}{l}\text { Remote and isolated Qld } \\
\text { No MO on site }\end{array}$ & $\begin{array}{l}\text { Multiple case study - } \\
\text { interviews, focus groups } \\
\text { part of a larger study of } \\
\text { role of nurses working in } \\
\text { remote or isolated areas } \\
\text { of Qld }\end{array}$ & $35 \mathrm{RNs}$ & $\begin{array}{l}\text { RN seen as substitute for GP } \\
\text { Torres Strait Model of care - RNs coach and are a } \\
\text { clinical resource for Indigenous Health Workers; } \\
\text { on call } \\
\text { Health service prioritise primary healthcare, but } \\
\text { RNs provide more of a bandaid service (acute } \\
\text { care) }\end{array}$ & $\begin{array}{l}\text { Need to develop model with } \\
\text { more emphasis on primary } \\
\text { healthcare }\end{array}$ \\
\hline $\begin{array}{l}\text { Courtney, } \\
\text { Yacopetti, } \\
\text { James, Walsh, } \\
\text { and Finlayson } \\
\text { (2002) }\end{array}$ & $\begin{array}{l}\text { Comparison of roles and } \\
\text { professional development } \\
\text { needs of nurse executives }\end{array}$ & $\begin{array}{l}\text { Qld (all) } \\
\text { Remote was defined as a } \\
\text { centre with a population } \\
<5000 \\
\text { Rural - an urban centre } \\
\text { with a population from } \\
5000-25000\end{array}$ & $\begin{array}{l}\text { Cross sectional self-report } \\
\text { descriptive study } \\
\text { Questionnaire survey tool }\end{array}$ & $\begin{array}{l}\text { All }(n=281) \text { Director } \\
\text { of Nursing (DON), } \\
\text { Assistant Director } \\
\text { of Nursing (ADON) } \\
\text { employed in Qld } \\
\text { public health service, } \\
\text { with min } 12 \text { months } \\
\text { experience }\end{array}$ & $\begin{array}{l}\text { DONs reported more diverse roles the further from } \\
\text { cities to remote - more clinical management } \\
\text { Clinical management most frequent role for } \\
\text { remote respondents, including 'general nursing } \\
\text { role' }\end{array}$ & $\begin{array}{l}\text { Response rate of } 52 \% \\
\text { (limitation) } \\
\text { Noted also, that perceptions } \\
\text { of geographical area or work } \\
\text { may have been interpreted } \\
\text { differently by participants and } \\
\text { limit findings }\end{array}$ \\
\hline Cramer (1998) & $\begin{array}{l}\text { Nursing practice in } \\
\text { a remote area: An } \\
\text { ethnographic study }\end{array}$ & $\begin{array}{l}\text { Remote Aboriginal } \\
\text { community in Western } \\
\text { Australian (WA) Central } \\
\text { Desert } \\
\text { No MO on site }\end{array}$ & $\begin{array}{l}\text { Qualitative Ethnographic } \\
\text { study } \\
\text { Interviewing and } \\
\text { participant observation }\end{array}$ & $\begin{array}{l}\text { Purposive sampling } \\
\text { - RNs employed at } \\
\text { remote area clinic } \\
\text { in WA desert over } \\
\text { a one-year period } \\
(n=19)\end{array}$ & $\begin{array}{l}\text { Themes - Detachment, diffusion, beyond the } \\
\text { nursing domain } \\
\text { Not prepared well for role } \\
\text { Expected to use treatment manual, which assumes } \\
\text { a diagnosis is made, but not trained in medical } \\
\text { diagnosis } \\
\text { Suddenly expected to do things outside of normal } \\
\text { nursing role (e.g. medical diagnosis) } \\
\text { Skills different from hospitals } \\
\text { Role like Nurse Practitioner } \\
\text { Many clinical skills required }\end{array}$ & $\begin{array}{l}\text { First research study providing } \\
\text { detailed description of remote } \\
\text { area nursing in Australia }\end{array}$ \\
\hline
\end{tabular}


TABLE 1: SUMMARY OF INCLUDED ARTICLES (CONTINUED)

\begin{tabular}{|c|c|c|c|c|c|c|}
\hline Study & Title & Setting/context & Method & Sample & Main findings (summary) & $\begin{array}{l}\text { Comments/ } \\
\text { recommendations }\end{array}$ \\
\hline $\begin{array}{l}\text { Crossland } \\
\text { (2011) }\end{array}$ & $\begin{array}{l}\text { Perceptions of roles and } \\
\text { skills of primary health } \\
\text { professionals - rural }\end{array}$ & $\begin{array}{l}\text { Rural } \\
\text { Remote } \\
\text { Four communities in North } \\
\text { Qld } \\
\text { Non-Indigenous } \\
\text { communities }\end{array}$ & $\begin{array}{l}\text { Collective case study } \\
\text { methodology; narrative } \\
\text { approaches, organisational } \\
\text { change theory }\end{array}$ & $\begin{array}{l}\text { One nurse from one } \\
\text { remote community } \\
\text { Multidisciplinary from } \\
\text { other communities }\end{array}$ & $\begin{array}{l}\text { Where no doctor on site, patients see nurses } \\
\text { as doing everything a doctor does - community } \\
\text { does not perceive GP as 'essential' healthcare } \\
\text { professional (note reference to practice nurses' } \\
\text { meaning RNs, and RIPERNs working in primary } \\
\text { healthcare settings (meets inclusion criteria) } \\
\text { RIPERNs akin to advanced nurse practitioners } \\
\text { RNs called themselves generalist, regardless of } \\
\text { service model worked in }\end{array}$ & $\begin{array}{l}\text { As communities' value non } \\
\text { GP led services, should be } \\
\text { supported as a service model } \\
\text { in its own right } \\
\text { - further research to define } \\
\text { flexibility of roles } \\
\text { Only one nurse sample for the } \\
\text { RIPERN }\end{array}$ \\
\hline $\begin{array}{l}\text { Josif, Kruske, } \\
\text { Kildea, and } \\
\text { Barclay (2017) }\end{array}$ & $\begin{array}{l}\text { Quality of health services } \\
\text { to remote dwelling infants }\end{array}$ & $\begin{array}{l}\text { Two Northern Territory } \\
\text { remote area Aboriginal } \\
\text { communities }\end{array}$ & $\begin{array}{l}\text { Qualitative } \\
\text { Semi structured interviews, } \\
\text { observation }\end{array}$ & $\begin{array}{l}24 \text { multidisciplinary } \\
\text { clinicians managing } \\
\text { child health services - } \\
\text { RNs } n=4\end{array}$ & $\begin{array}{l}\text { Some misunderstanding of the primary health role } \\
\text { by RANs } \\
\text { Saw acute as being more relevant to their practice } \\
\text { (even though most presentations were related to } \\
\text { primary healthcare) } \\
\text { RANs were immunising and running baby clinics, } \\
\text { often unprepared }\end{array}$ & $\begin{array}{l}\text { Need better preparation for } \\
\text { roles; better service design } \\
\text { Urgently need better } \\
\text { management practices for } \\
\text { better quality care }\end{array}$ \\
\hline $\begin{array}{l}\text { Hegney, } \\
\text { McCarthy, and } \\
\text { Pearson (1999) }\end{array}$ & $\begin{array}{l}\text { Effects of size of health } \\
\text { service on scope of rural } \\
\text { nursing practice (analysis } \\
\text { of the activities of rural } \\
\text { nurses from a national audit } \\
\text { in 1996) }\end{array}$ & $\begin{array}{l}\text { Australia wide } \\
\text { Rural defined in study } \\
\text { as taking place in a rural } \\
\text { environment where there } \\
\text { are no full time on site } \\
\text { medical and allied health } \\
\text { practitioners/often no } \\
\text { support from MO or allied } \\
\text { health }\end{array}$ & $\begin{array}{l}\text { Qualitative } \\
\text { Nurses observed over 24- } \\
\text { hour period - all activities } \\
\text { undertaken recorded }\end{array}$ & $\begin{array}{l}\text { Random sample of } \\
129 \text { health services } \\
\text { and } 362 \text { nurses } \\
\text { employed in the } \\
\text { health services (p. 22) }\end{array}$ & $\begin{array}{l}\text { Size of health service influences staffing type and } \\
\text { ratio } \\
\text { Jack of all trades/multi-skilled } \\
\text { Flexible (25\%) } \\
\text { Increased level of responsibility } \\
\text { No support in emergency situations } \\
\text { Concern of legal issues associated with extended } \\
\text { role } \\
\text { Non-nursing duties } \\
\text { Three categories of health service identified - } \\
\text { varying roles depending on size of health service - } \\
\text { smaller health service = broader range of skills }\end{array}$ & $\begin{array}{l}\text { Further research into impact } \\
\text { of skill mix and patient acuity } \\
\text { Extended role needs to be } \\
\text { recognised }\end{array}$ \\
\hline $\begin{array}{l}\text { Smith and } \\
\text { Jones, (2007) }\end{array}$ & $\begin{array}{l}\text { Remote } x \text {-ray operator } \\
\text { radiography: a case study } \\
\text { in inter-professional rural } \\
\text { clinical practice }\end{array}$ & $\begin{array}{l}\text { NSW - All remote } x \text {-ray } \\
\text { operators i.e. where a } \\
\text { radiographer not available }\end{array}$ & $\begin{array}{l}\text { Qualitative case study } \\
\text { Semi structured in depth } \\
\text { interviews - }\end{array}$ & $\begin{array}{l}\text { Multidisciplinary } \\
\text { clinicians, including } \\
10 \text { RNs } \\
\text { Purposeful sampling }\end{array}$ & $\begin{array}{l}\text { RNs taking on x-ray role in areas where } \\
\text { radiographers not available - upper limb, shoulder, } \\
\text { chest, lower limb, pelvis } \\
\text { Radiographers feel the quality is below standards; } \\
\text { RNs impinging on their role } \\
\text { General acceptance that if no one else to do it, } \\
\text { then it is ok for RNs, regardless of quality to meet } \\
\text { community needs }\end{array}$ & $\begin{array}{l}\text { Better communication and } \\
\text { collaboration needed } \\
\text { Cross disciplinary education } \\
\text { required }\end{array}$ \\
\hline
\end{tabular}


TABLE 1: SUMMARY OF INCLUDED ARTICLES (CONTINUED)

\begin{tabular}{|c|c|c|c|c|}
\hline Study & Title & Setting/context & Method & Sample \\
\hline \multicolumn{5}{|c|}{ Practice literature/Other } \\
\hline $\begin{array}{l}\text { Greene and } \\
\text { Burley (2006) }\end{array}$ & $\begin{array}{l}\text { The changing role of bush } \\
\text { nurses in East Gippsland, } \\
\text { Victoria }\end{array}$ & $\begin{array}{l}\text { Five bush nursing centres in } \\
\text { Victoria } \\
\text { Single nurse posts } \\
\text { No doctor or pharmacist } \\
\text { Non Indigenous }\end{array}$ & $\begin{array}{l}\text { Discussion based on research } \\
\text { study by authors }\end{array}$ & $\begin{array}{l}24 \text { hour primary health service } \\
\text { Traditional roles broadening in response to community needs and advances in nursing practice } \\
\text { (specific roles detailed in paper) }\end{array}$ \\
\hline Hegney (1996) & $\begin{array}{l}\text { The status of rural nursing in } \\
\text { Australia: A review }\end{array}$ & $\begin{array}{l}\text { Focus on rural rather than remote } \\
\text { RN } \\
\text { Non indigenous }\end{array}$ & Narrative review & $\begin{array}{l}\text { Rural nurses - Rural hospitals, community health settings, nursing homes (defines remote as } \\
\text { more Aboriginal and Torres Strait Islander primary healthcare services). } \\
\text { Work beyond legal boundaries } \\
\text { Extended into doctor and allied health roles } \\
\text { Context impacts on role (e.g. location, population density, community needs } \\
\text { High responsibility } \\
\text { On call } \\
\text { Multi-skilled - (skills defined in paper) } \\
\text { Work beyond legal boundaries } \\
\text { Autonomous }\end{array}$ \\
\hline Hegney (1997) & $\begin{array}{l}\text { Extended, expanded, multi- } \\
\text { skilled or advanced practice? } \\
\text { Rural nurses in Australia, } \\
\text { 1991-1994 }\end{array}$ & $\begin{array}{l}\text { Rural settings in all Australian } \\
\text { states (except NT which is } 98 \% \\
\text { remote) p. } 23\end{array}$ & $\begin{array}{l}\text { Uses Foucault's framework to } \\
\text { examine public and workplace } \\
\text { discourses of rural nursing } \\
\text { 1991-1994 In addition, } 30 \text { RNs } \\
\text { Purposive sampling }\end{array}$ & $\begin{array}{l}\text { Extended role to fill the gap, otherwise the service would not exist } \\
\text { Size of rural facility and type of support impacts on scope of practice (Smaller = more } \\
\text { autonomous and expected to do more) } \\
\text { Proposes that advanced rural nursing practice be used to refer to the generalist scope }\end{array}$ \\
\hline NRHA, (2005) & $\begin{array}{l}\text { Advanced nursing practice in } \\
\text { rural and remote areas }\end{array}$ & Rural and remote (broadly) & Position paper & $\begin{array}{l}\text { Many experienced registered nurses in rural and remote areas are already practicing in } \\
\text { advanced levels but are not nurse practitioners. They need to be recognised } \\
\text { Remote nurses work in indigenous communities, islands, tourist centres, mining, pastoral, } \\
\text { fishing communities, jails, refugee camps, emergency retrieval services } \\
\text { Remote Area Nurses (RAN) - care across the lifespan } \\
\text { Non-clinical roles, e.g. vehicle maintenance }\end{array}$ \\
\hline $\begin{array}{l}\text { Taylor, } \\
\text { Usher, and } \\
\text { McDermott } \\
(2013)\end{array}$ & $\begin{array}{l}\text { Diabetes in Torres Strait } \\
\text { Islanders: Challenges and } \\
\text { opportunities for remote area } \\
\text { nurses }\end{array}$ & Torres Strait Islands, Remote Qld & Discussion paper & $\begin{array}{l}\text { RANs in remote primary healthcare centres in Torres Strait Islands (21 Primary Healthcare } \\
\text { Centres) } \\
\text { Nurses have role to: Manage, educate, screen, assist with new models of care related to } \\
\text { diabetes (need to not just focus on acute care, but also primary care) }\end{array}$ \\
\hline $\begin{array}{l}\text { Timmings } \\
(2006)\end{array}$ & $\begin{array}{l}\text { Rural and Isolated Practice } \\
\text { Registered Nurse (RIPRN) - } \\
\text { emergency nurses of the Qld } \\
\text { 'bush'. }\end{array}$ & $\begin{array}{l}\text { Discussion on how nurses in } \\
\text { rural areas in Qld can gain } \\
\text { an endorsement as a RIPRN } \\
\text { to enable more autonomous } \\
\text { practice }\end{array}$ & Expert opinion & $\begin{array}{l}\text { RIPRN nurses administer and supply medicines legally, using the Primary Clinical Care Manual; } \\
\text { Able to do assessment, diagnose and manage with or without doctor }\end{array}$ \\
\hline
\end{tabular}




\section{DATA ANALYSIS}

Data was extracted into a table using pre-determined headers of specific criteria. Headers included: the purpose of the paper or study, focus, analysis, methodology, context/setting, sample details, findings, and gaps identified for future research.

As the papers were either qualitative research or practice literature, a thematic analysis was used. A thematic analysis is also appropriate for a systematic narrative synthesis of the literature, such as this paper provides..$^{30}$ The analysis was completed manually and included familiarising and reviewing the findings of each research paper by reading, re-reading, and highlighting important or recurring themes. ${ }^{12}$ Evolving themes were tabulated to visualise results and enable comparisons to each paper. Themes of prominence were then able to be identified..$^{12,30}$ Thematic analysis was performed by the lead author, with the second author verifying the analysis to assist in reducing bias. ${ }^{31}$

Initial analysis of the papers established six were focused on remote areas, five on rural areas, and three on rural and remote areas. The parameters around what constitutes rural and remote has some variation within the papers. For the purposes of this review, 'rural and remote' will not be defined further, and rather will be referred to as presented by the author/s of each publication.

\section{RESULTS}

Four main themes were identified: roles shaped by context; doctor substitute; multi-skilled and advanced practice; and feeling unprepared.

\section{ROLES SHAPED BY CONTEXT}

Two subthemes were identified within this theme in relation to the influence context has on the role of the rural and remote RN: the size of the health service and the needs of the community.

Many authors agree the smaller the facility the more generalised the role of the RN becomes. ${ }^{24,26,28,32}$ In a report of a larger study in the 1990s, Hegney et al. analysed activities undertaken by 362 RNs from a random sample of 129 rural health services across Australia. ${ }^{26}$ The services were categorised by the number of acute (inpatient) beds in the service. Hegney et al. revealed that there was a significant difference in the activities of RNs in relation to the size of the health service in which they worked, with RNs from the smaller services requiring a broader range of knowledge and skills. ${ }^{26}$ This was reflective of the findings of an examination of discourses of rural nursing from 1991-1994 by Hegney, ${ }^{32}$ who concluded that the smaller the facility, the less access and support from medical and allied health staff, and therefore the more extended the role of the RN became in order to "fill the gap". ${ }^{32(\mathrm{p} 27)}$
Later studies report similar findings. Using a collective case study design, Crossland investigated the perceptions of the roles of health professionals in four rural and remote north Queensland communities. ${ }^{24}$ The findings suggest that RNs in single nurse posts undertake much broader roles than RNs in communities with additional health professionals on the ground. ${ }^{24}$ Similarly, in a study of the roles of nurse executives across Queensland, Courtney et al. reported Directors of Nursing roles became much broader and more clinically focused the further away from cities they worked..$^{28}$

The needs of the community were also shown to impact on the roles of rural and remote RNs. Rural and remote RNs service a diverse range of communities, for example, "islands, tourist centres, mine(s), pastoral (and) fishing communities ...jails, refugee camps ... emergency retrieval services".33(p8) and Aboriginal and Torres Strait Islander communities. ${ }^{23}, 25,27,34$

Several authors indicated that the RN's role requires flexibility to be able to respond to community needs. ${ }^{22,25,27,34,35}$ Greene and Burley,35 for example, discussed how the practice of RNs in bush nursing centres in Victoria is shaped by an ageing population, increasing mental health needs, and the health needs of farmers and their families.

The social determinants of health and disease patterns in Aboriginal and Torres Strait Islander communities further influence the roles required of rural and remote RNs. ${ }^{22,25,27,34}$ RNs in these communities are required to undertake a range of health promotion and prevention activities and management of chronic diseases. ${ }^{22,25,27,34}$ Taylor et al. for example argued that significantly high rates of diabetes in people living on the outer islands of the Torres Straits presented an enormous challenge for the RNs working in that area. ${ }^{34}$ Similarly, Al-Motlaq et al. explored how remote or isolated RNs addressed the burden of chronic disease. ${ }^{22}$ Using a multiple case study approach, the authors reported that RNs from a non-Indigenous community prioritised acute care and trauma services, whereas RNs from the Aboriginal communities saw diabetes management and teaching chronic disease self-management as a core focus of their work. ${ }^{22}$ In the same vein, Josif et al. reported that the significant amount of malnutrition, anaemia and acute illnesses in children in two Northern Territory remote area Aboriginal communities required RNs to incorporate a child health focus to their role. ${ }^{27}$

\section{DOCTOR SUBSTITUTE}

A number of authors revealed that rural and remote RNs often acted as substitutes for general practitioners (GPs). ${ }^{11}$, 23-25, 32, 33, 35, 36 The substitute GP role is reportedly undertaken in rural areas when the doctor is off site, and the RN becomes the first point of care for patient presentations. ${ }^{11,32,33,36}$ As the health facility becomes more remote it becomes usual practice for RNs to take on the GP substitute role in its 
entirety, while collaborating with GPs, nurse practitioners and other experts via distance communication strategies, or during periodic community visits. ${ }^{22-25,33,35}$

Cramer exemplified the medical role of remote area RNs in her research in a remote Western Australian Aboriginal community. 25 The community had a population of 515 people, with a health centre staffed by three RNs, and a doctor off site. Cramer observed 19 RNs while living in the community for 12 months. ${ }^{25}$ She concluded it was normal practice for RNs to undertake medical histories and physical examinations, order pathology tests, and make medical diagnoses. There was also an expectation from doctors and management that the RNs would perform these roles. ${ }^{25}$

Crossland reported similar findings in her study of rural and remote communities in North Queensland. ${ }^{24}$ In one community, with a population of 200 people, the primary healthcare clinic had no doctor on site and was staffed by a RN with the RIPRN qualification. Crossland found that the community perceived the service provided by RNs with the RIPRN qualification as being no different to a GP service, with many patients not concerned about the lack of a GP on site. ${ }^{24}$ Of note, Crossland only included one RIPRN qualified RN in her research and did not differentiate between the roles of a $\mathrm{RN}$ without this qualification in a similar context, or to that of a nurse practitioner. ${ }^{24}$

Birks et al. reported that RNs with the RIPRN qualification were more likely to take on a GP role than other RNs, because of the added authority to initiate medicines. ${ }^{23}$ Other studies reported that community members generally accept RNs providing primary care and have an expectation that RNs will assume a GP role when doctors are not available. ${ }^{11,33,35}$

Some authors noted that RNs working in rural and remote areas are also sometimes required to assume allied health roles, such as taking x-rays, pharmacy dispensing, and being the ambulance first responder. ${ }^{11,24,25,32,33,37}$

\section{MULTI-SKILLED AND ADVANCED PRACTICE}

The majority of authors agree that rural and remote RNs are required to be multi-skilled, and often practice at an advanced level. ${ }^{11,24-26,32,33,35,3^{6}}$ Rural RNs may adopt a generalist or specialist role, depending on the setting, 33 with Hegney suggesting a typical day for a generalist rural RN could include working across an array of areas, such as paediatrics, medical and surgical, midwifery, aged care, operating theatre, and emergency. ${ }^{11}$

Remote area RNs conversely have much broader roles. ${ }^{33}$ The National Rural Health Alliance (NRHA) argue that it is essential for all remote area RNs to practice at an advanced level in a generalist role. 33 Remote area RNs are required to deliver care across the lifespan, including "maternal, infant and child health, adolescent health, mental health, women's and men's health, aged care, palliative care, emergency care, retrieval and transfer, and public health
... including ... communicable diseases and chronic illness management". $33(\mathrm{pg})$

All authors identified multiple clinical roles undertaken by rural and remote RNs. These roles are summarised in Table 2.

In addition to clinical roles, an array of non-clinical roles are often undertaken by rural and remote RNs, for example, domestic/general cleaning, ${ }^{25,26,33}$ food preparation, repairs, general maintenance, security checking, ${ }^{26}$ maintaining records and files, ${ }^{25}$ reception and administrative work, ${ }^{24,35}$ vehicle maintenance, and animal health. ${ }^{33}$

\section{FEELING UNPREPARED}

The final theme identified, was that rural and remote RNs often report feeling unprepared for their extended roles, yet they still perform the roles in order to meet community needs. ${ }^{11,22,25-27,32,33}$ The authors of two papers have suggested that the quality of care in the remote Aboriginal communities they studied is often dependant on the experience and expertise of the RNs who were commonly employed straight from acute hospital settings. ${ }^{25,27}$ Both authors expressed significant concerns about the quality of care provided to Aboriginal people by RNs who lacked context specific expertise. ${ }^{25,27}$ For example, Josif et al. purposively interviewed four RNs, who were providing child health services to two remote Aboriginal communities in the Northern Territory. ${ }^{27}$ The RNs generally reported feeling unprepared for this role, however voiced concerns that it was an employer expectation to perform these roles regardless. ${ }^{27}$ One RN said, "you're expected to do the job without the background, without the knowledge”, ${ }^{27(\mathrm{p} 7)}$ and "we're all trained in accident and emergency or ... coronary care or intensive care but it is primary healthcare here so we really do need more training". ${ }^{2(\mathrm{p} 6)}$ It is noteworthy that one third of presentations to the health services were for child health or non-acute service provision. ${ }^{27}$

Similarly, Cramer found that new RNs felt 'thrown in' to the remote Western Australian community of her study. ${ }^{25}$ RNs reportedly were expected to use a practice manual to guide practice, albeit unprepared, as the manual assumed competence in medical diagnosis, which the nurses lacked. ${ }^{25}$ Table 3 maps the themes to each paper. 
TABLE 2: SUMMARY OF CLINICAL SKILLS AND ROLES

\begin{tabular}{|c|c|c|c|}
\hline Clinical skills/roles & Rural & Remote & Source \\
\hline $\begin{array}{l}\text { Sexually transmitted infections } \\
\text { diagnosis and treatment }\end{array}$ & & $\sqrt{ }$ & Al-Motlaq et al., 2010; Cramer, 1998 \\
\hline Women's health/family planning & $\sqrt{ }$ & $\checkmark$ & Cramer, 1998; Greene and Burley, 2006; Hegney, 1997; NRHA, 2005 \\
\hline Men's health & & $\sqrt{ }$ & NRHA, 2005 \\
\hline Renal disease management & & $\checkmark$ & Cramer, 1998 \\
\hline Initiating medicines & $\sqrt{ }$ & $\sqrt{ }$ & Birks et al., 2010; Cramer, 1998; Crossland, 2011; NRHA, 2005; Timmings, 2006 \\
\hline Emergency care & $\checkmark$ & $\checkmark$ & $\begin{array}{l}\text { Al-Motlaq et al., 2010; Birks et al., } 2010 \text {; Cramer, 1998; Crossland, 2011; } \\
\text { Hegney et al., 1999; Josif et al., 2017; NRHA, } 2005\end{array}$ \\
\hline Midwifery/antenatal care & $\sqrt{ }$ & $\sqrt{ }$ & (Cramer, 1998; Hegney, 1996; NRHA, 2005) \\
\hline Paediatrics/child health & $\sqrt{ }$ & $\checkmark$ & Cramer, 1998; Josif et al., 2017; NRHA, 2005 \\
\hline Acute care & $\sqrt{ }$ & $\checkmark$ & $\begin{array}{l}\text { Al-Motlaq et al., 2010; Birks et al., 2010; Cramer, 1998; Crossland, 2011; Greene } \\
\text { and Burley, 2006; Hegney, 1996; Josif et al., 2017; Timmings, } 2006\end{array}$ \\
\hline Chronic disease & & $\sqrt{ }$ & Al-Motlaq et al., 2010; Birks et al., 2010; NRHA, 2005 \\
\hline Mental health & & $\checkmark$ & Al-Motlaq et al., 2010; Greene and Burley, 2006; NRHA, 2005 \\
\hline Dental problems & & $\sqrt{ }$ & Al-Motlaq et al., 2010 \\
\hline $\begin{array}{l}\text { Infections (e.g. skin, gastroenteritis, } \\
\text { ears, nose throat) }\end{array}$ & & $\sqrt{ }$ & Al-Motlaq et al., 2010 \\
\hline Trauma/pre-hospital trauma & & $\sqrt{ }$ & Crossland, 2011 \\
\hline Abuse disorders & & $\sqrt{ }$ & Cramer, 1998 \\
\hline Ambulance/first responder & & $\checkmark$ & Crossland, 2011 \\
\hline Immunisation & & $\checkmark$ & Cramer, 1998; Greene and Burley, 2006; Josif et al., 2017 \\
\hline Health promotion & & $\checkmark$ & $\begin{array}{l}\text { Al-Motlaq et al., 2010; Birks et al., 2010; Crossland, 2011; Greene and Burley, } \\
\text { 2006; Josif et al., 2017; Taylor et al., } 2013\end{array}$ \\
\hline Palliative care & & $\sqrt{ }$ & Greene and Burley, 2006; NRHA, 2005 \\
\hline Aged care & $\sqrt{ }$ & & Hegney, 1996; NRHA, 2005 \\
\hline Order pathology tests & & $\sqrt{ }$ & Cramer, 1998 \\
\hline Medical diagnosis & $\checkmark$ & $\checkmark$ & $\begin{array}{l}\text { Birks et al., 2010; Cramer, 1998; Crossland, 2011; Greene and Burley, 2006; } \\
\text { Hegney, 1996, 1997; NRHA, 2005; Timmings, } 2006\end{array}$ \\
\hline $\begin{array}{l}\text { Aboriginal and Torres Strait Islander } \\
\text { health related conditions }\end{array}$ & & $\sqrt{ }$ & $\begin{array}{l}\text { Al-Motlaq et al., 2010; Birks et al., 2010; Cramer, 1998; Josif et al., 2017; NRHA, } \\
\text { 2005; Taylor et al., } 2013\end{array}$ \\
\hline Suturing & $\sqrt{ }$ & $\checkmark$ & Cramer, 1998; Crossland, 2011; Hegney, 1997; Timmings, 2006 \\
\hline Plastering & & $\checkmark$ & Crossland, 2011 \\
\hline Intraosseous insertion & & $\checkmark$ & Cramer, 1998 \\
\hline Storage, dispensing medicines & $\sqrt{ }$ & $\checkmark$ & Birks et al., 2010; Cramer, 1998; Hegney, 1997 \\
\hline X-rays & $\checkmark$ & $\checkmark$ & Crossland, 2011; Hegney, 1996; Smith and Jones, 2007 \\
\hline
\end{tabular}

\section{TABLE 3: THEMES MAPPED TO PUBLICATION}

\section{Theme}

\section{Roles shaped by context}

Subtheme 1 - Size of health service

Subtheme 2 - Needs of the community

\section{Doctor substitute}

Multi-skilled and advanced practice

Feeling unprepared

\section{Articles}

Courtney, Yacopetti, James, Walsh and Finlayson, 2002; Cramer, 1998; Crossland, 2011; Hegney, 1996 1997; Hegney, McCarthy and Pearson, 1999

Al-Motlaq, Mills, Birks and Francis, 2010; Cramer, 1998; Greene and Burley, 2006; Josif, Kruske, Kildea and Barclay, 2017; NRHA, 2005; Taylor, Usher and McDermott, 2013

Birks et al., 2010; Cramer, 1998; Crossland, 2011; Hegney, 1996, 1997; NRHA, 2005; Timmings, 2006

Al-Motlaq et al., 2010; Birks et al., 2010; Cramer, 1998; Crossland, 2011; Greene and Burley, 2006; Hegney, 1996, 1997; Josif et al., 2017; Smith and Jones, 2007; Timmings, 2006

Al-Motlaq et al., 2010; Cramer, 1998; Greene and Burley, 2006; Hegney, 1996, 1997; Hegney et al., 1999; Josif et al., 2017 
There is consensus amongst many authors that if rural and remote RNs are to continue to practice in an extended role, then they need structured, affordable and accessible education to build their skill level appropriate to the community and health service needs..$^{11,22,32,33,35}$

\section{DISCUSSION}

This literature review aimed to investigate the multifaceted role of the RNs working in rural and remote areas of Australia. From a chronological perspective, the findings of the more recent papers were not dissimilar to those of the older papers reviewed, suggesting that the role of the rural and remote RN has not changed significantly in the past 20 years.

The findings of this review indicate that the most significant influence on the roles of rural and remote RNs lies within the context in which they practice, including the size of the health service and the needs of the community. This is similar to reports by Lenthall and Smith,,$^{8}$ and Whitehead et al., ${ }^{39}$ who identified a number of factors that characterise healthcare in rural and remote practice, including the relationship with the community, workforce supply, available resources and the need to work as part of an interdisciplinary team.

The distribution of health professionals across Australia is geographically disproportionate, particularly in respect of doctors. ${ }^{40}$ As has been found in this review, Lenthall and Smith also reiterate that RNs are consequently required to undertake activities that would normally be the domain of doctors in less isolated contexts. ${ }^{38}$ In a scoping review, Burrows, Calleja and Cook similarly report that rural nurses felt they needed more recognition of these extended roles, particularly as they are often working alone with a high degree of autonomy with minimal resources. ${ }^{41}$

In addition to stepping up to "fill the gap" by assuming the roles of other healthcare professionals, ${ }^{32\left({ }^{223}\right)}$ Lenthall and Smith also report RNs in rural and remote areas may be required to demonstrate an extended knowledge and skills base from within their own discipline to enable them to meet the healthcare needs of their diverse populations. ${ }^{38}$

This review has reinforced the concept of the advanced generalist role in rural and remote areas. Lenthall and Smith, ${ }^{8}$ in discussing the unique context of nonmetropolitan healthcare, also identify the need for a breadth of understanding of diverse content areas. These content areas include discipline specific knowledge, such as those identified in this review (Table 2) as well as context specific skills in areas such as tele-health, cross-cultural communication and Indigenous health..$^{3}$ As is evidenced by this work, the requirement to possess such a broad, adaptable skill set, often in the context of isolated practice, can leave RNs feeling unprepared for this role, or lacking in expertise needed to address the community's health priorities.
A key strategy in ensuring that RNs working in rural and remote areas are adequately prepared for their role is the development of educational programs that are tailored to address the complexity of nursing in this unique context. Educational pathways need to consider the diversity of these roles and acknowledge that acting in the stead of a medical practitioner is often a normal part of the RNs practice. The RN's existing experience and expertise should be considered, along with the impact of the high turnover of RNs in these areas. 5 Whitehead et al. highlight that unnecessary barriers to practice such as mandating credentialling of rural and remote nurses should be avoided, however agree that accessibility to education for rural and remote nursing needs to increase. 39

An example of a suggested model for addressing education considerations is presented in Figure 2. This model addresses the distinction, albeit sometimes blurred, between rural and remote nursing as suggested in the papers reviewed. These distinctions impact on the education needs of RNs working in each location. As established in this review, a 'one size fits all' approach would not be appropriate, but rather education pathways should be flexible and be offered along a continuum. Approaches such as micro-credentialling or programs with multiple entry and exit points that meet an individual's educational needs are more likely to ensure timely preparedness for practice in a given context. Flexibility such as this may be better suited to rural and remote RNs who generally stay in positions for shorter periods than metropolitan RNs. 5

The scarcity of recent research around the roles of rural and remote RNs highlights the need for more work in this area. Future research could include an evaluation of existing models of practice in rural and remote areas. Other research should evaluate the skills required by rural and remote RNs who are often required to substitute for doctors. How these nurses currently prepare for and are supported in this role; the quality of care provided by RNs who undertake medical diagnoses; and how this contributes to meeting community needs warrants specific consideration.

\section{LIMITATIONS}

The lack of contemporary research that was located examining rural and remote $\mathrm{RN}$ roles could be a limitation to this review, with nine of the 14 papers reviewed published 10 years or more ago. This may indicate that little research has been completed on the roles of rural and remote RNs within the last decade. Another limitation of this review may be the exclusion of grey literature, for example policy or government documents and position descriptions, ${ }^{12}$ which may have added valuable insight into the role of rural and remote RNs. The lack of consistency around what constitutes rural and remote regarding the RNs roles may also be a limitation to the findings. 


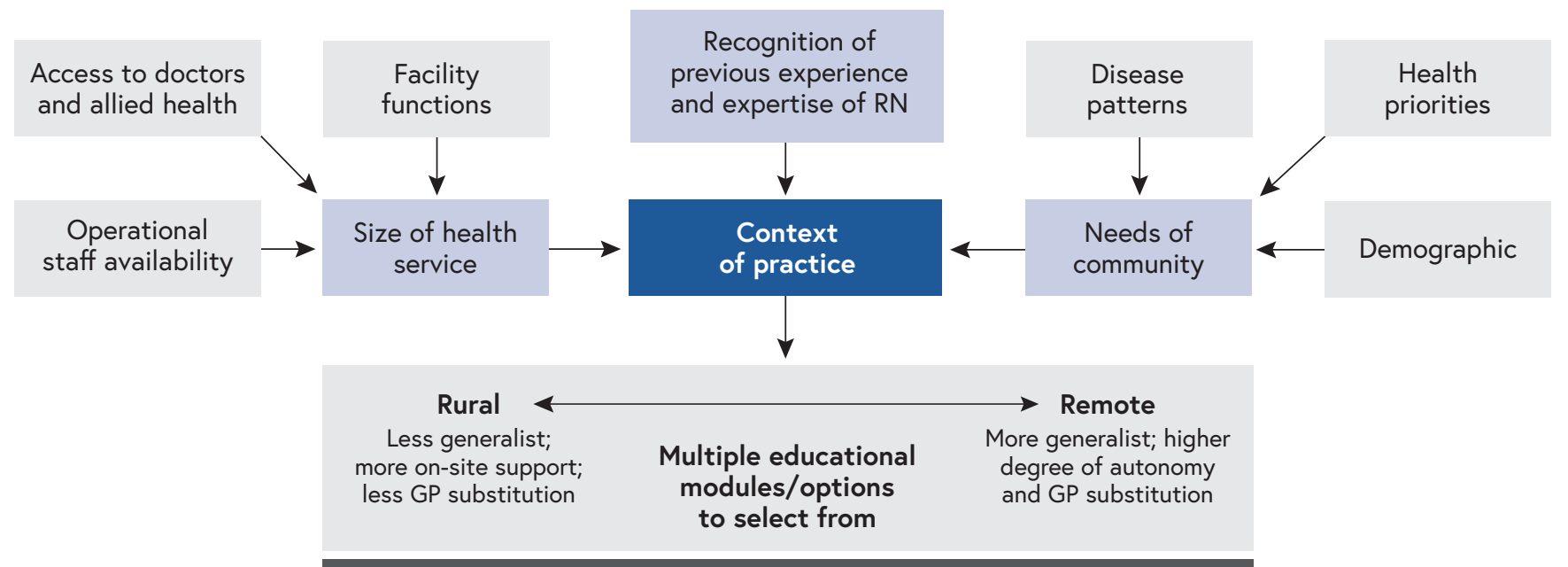

Flexible, accessible, affordable

FIGURE 2: CONSIDERATIONS FOR EDUCATIONAL PLANNING

As with any review process, there are limitations to note in respect of this review. Of the literature found, there were no quantitative studies. While the qualitative studies located were assessed as being of good quality, the generation of themes from qualitative studies can be subjective, and be dependent on the authors insight ${ }^{12}$. Bias may have been introduced into the review process through a slight amendment of the inclusion criteria after the review had commenced, and the review process being led by a single author with a second author verifying the process and findings.

\section{CONCLUSION}

With the findings of this review in mind, strategic planning to improve rural and remote health access should acknowledge that rural and remote RNs are already practicing in extended and advanced generalist roles and have been for some time. Nursing and medical leaders need to appreciate that rural and remote RNs diagnose as a normal part of their role and need to be educationally prepared and supported accordingly. Development of models for rural and remote practice should prioritise the development of a supportive framework for existing and novice rural and remote RNs, which differentiates and defines their roles according to context, integrates appropriate clinical governance, and enables flexible educational pathways.

Funding support: No funding was received for the completion of this review.

Declaration of conflicting interests: The authors have no conflict of interest to disclose.

\section{REFERENCES}

1. Australian Bureau of Statistics. Regional population growth, Australia, 2014-15 [Internet]. ACT: Commonwealth of Australia; 2016. http://www.abs.gov.au/ausstats/abs@.nsf/mf/3218.0 (accessed 8 Sep 2017)

2. Australian Institute of Health and Welfare. The health and welfare of Australia's Aboriginal and Torres Strait Islander peoples: 2015 [Internet]. Canberra: AlHW; 2015. https://www. aihw.gov.au/reports/indigenous-health-welfare/indigenoushealth-welfare-2015/contents/table-of-contents (accessed 12 Oct 2017).

3. Australian Institute of Health and Welfare. Australia's health 2016 [Internet]. Canberra: AlHW; 2016. https://www.aihw.gov. au/reports/australias-health/australias-health-2016/contents/ summary (accessed 12 Oct 2017).

4. Australian Government. National strategic framework for rural and remote health [Internet]. ACT: Commonwealth of Australia; 2011. https://www1.health.gov.au/internet/main/publishing. nsf/Content/national-strategic-framework-rural-remote-health (accessed 14 Oct 2017).

5. Russell DJ, Zhao Y, Guthridge S, Ramjan M, Jones MP, Humphreys JS, et al. Patterns of resident health workforce turnover and retention in remote communities of the Northern Territory of Australia, 2013-2015. Hum Resour Health [Internet]. 2017; 15(1):52-12. https://human-resources-health. biomedcentral.com/articles/10.1186/s12960-017-0229-9\%20 (accessed 12 Jul 2018).

6. Queensland Government. Advancing rural and remote health service delivery through workforce: a strategy for Queensland 2017-2020 [Internet]. Brisbane: State of Queensland (Queensland Health); 2017. https://www.health.gld.gov.au/ system-governance/strategic-direction/plans/rural-remoteworkforce-strategy (accessed 14 Oct 2017).

7. Cunningham Centre. Rural and isolated practice (scheduled medicines) registered nurse course [Internet]. QLD: Queensland Government; 2018. https://www.health.qld.gov.au/ cunninghamcentre/html/courses/022 (accessed $12 \mathrm{Jul}$ 2018). 
8. Souza MT, Silva MD, Carvalho R. Integrative review: what is it? How to do it? Einstein (São Paulo). 2010; 8(1): 102-6. http:// dx.doi.org/10.1590/s1679-45082010rw1134 (accessed 12 Oct 2019).

9. Moher D, Shamseer L, Clarke M, Ghersi D, Liberati A, Petticrew $M$, et al. Preferred reporting items for systematic review and meta-analysis protocols (PRISMA-P) 2015 statement. Syst Rev. 2015; 4(1): 148-60. https://doi.org/10.1186/2046-4053-4-1 (accessed 13 Oct 2019).

10. Torraco RJ. Writing integrative literature reviews: guidelines and examples. Hum Resour Dev Rev. 2005; 4(3): 356-67.

11. Hegney D. The status of rural nursing in Australia: a review. Aust J Rural Health. 1996; 4(1): 1-10.

12. Aveyard $\mathrm{H}$. Doing a literature review in health and social care a practical guide. 3rd ed. England: McGraw Hill Education; 2014.

13. Coyle M, Al-Motlaq MA, Mills J, Francis K, Birks M. An integrative review of the role of registered nurses in remote and isolated practice. Aust Health Rev. 2010; 34(2): 239-45.

14. Francis K, Bowman S, Redgrave M. Knowledge and skills required by rural nurses to meet the challenges of a changing work environment in the 21st century: a review of the literature. Canberra (ACT): National Review of Nursing Education: literature reviews; 2002. https://www.voced.edu.au/content/ ngv\%3A27789 (accessed 14 Oct 2017).

15. Mills J, Birks M, Hegney D. The status of rural nursing in Australia: 12 years on. Collegian. 2010; 17(1): 30-7.

16. Cramer JH. Amorphous practice: nursing in a remote Indigenous community of Australia. Contemp Nurse. 2006; 22(2): 191-202.

17. Hegney D, Pearson A, McCarthy A. The role and function of the rural nurse in Australia. Melbourne: Royal College of Nursing Australia; 1997. p. 4-34.

18. Allen C, Richmond K. The Cochrane Collaboration: International activity within Cochrane review groups in the first decade of the twenty-first century. J Evid Based Med. 2011; 4(1): 2-7.

19. Tyndall J. How low can you go? Towards a hierarchy of grey literature. Dreaming08: Australian Library and Information Association Biennial Conference; Alice Springs. 2008 2-5 September.

20. Rosenberg JP, Canning DF. Palliative care by nurses in rural and remote practice. Aust J Rural Health. 2004; 12(4): 166

21. Bagg J. Rural nurse practitioners in South Australia: recognition for registered nurses already fulfilling the role. Aust J Rural Health. 2004; 12(1): 3-5.

22. Al-Motlaq M, Mills J, Birks M, Francis K. How nurses address the burden of disease in remote or isolated areas in Queensland. Int J Nurs Pract. 2010; 16(5): 472-7.

23. Birks M, Mills J, Francis K, Coyle M, Davis J, Jones J. Models of health service delivery in remote or isolated areas of Queensland: a multiple case study. Aust J Adv Nurs. 2010; 28(1): 25-34.

24. Crossland L. Perceptions of the roles and skills of primary health professionals: implications for innovative and sustainable rural primary health care delivery [dissertation]. Townsville (Qld) James Cook University; 2011.

25. Cramer JH. Nursing practice in a remote area: an ethnographic study [dissertation]. Perth (WA): Curtin University of Technology; 1998.

26. Hegney D, McCarthy A, Pearson A. Effects of size of health service on scope of rural nursing practice. Collegian. 1999; 6(4): $21-6,42$
27. Josif CM, Kruske S, Kildea SV, Barclay LM. The quality of health services provided to remote dwelling aboriginal infants in the top end of northern Australia following health system changes: a qualitative analysis. BMC Pediatr. 2017; 17(93): 1-12.

28. Courtney M, Yacopetti J, James C, Walsh A, Finlayson K. Comparison of roles and professional development needs of nurse executives working in metropolitan, provincial, rural or remote settings in Queensland. Aust J Rural Health. 2002; 10(4): 202-8.

29. Moher D, Liberati A, Tetzlaff J, Altman DG, The Prisma Group. Preferred reporting items for systematic reviews and metaanalyses: the PRISMA statement. PLoS Med. 2009; 6(7). E1000097. https://doi.org/10.1371/journal.pmed.1000097 (accessed 12 Oct 2019).

30. Centre for Reviews and Dissemination. Systematic reviews: CRD's guidance for undertaking reviews in healthcare. United Kingdom: CRD, University of York 2009. https://www.york. ac.uk/media/crd/Systematic Reviews.pdf (accessed 13 Oct 2019).

31. Shamseer L, Moher D, Clarke M, Ghersi D, Liberati A, Petticrew $M$, et al. Preferred reporting items for systematic review and meta-analysis protocols (PRISMA-P) 2015: elaboration and explanation. BMJ. 2015; 349: 1-25. https://doi.org/10.1136/bmj. g7647 (accessed 12 Oct 2019).

32. Hegney D. Extended, expanded, multi-skilled or advanced practice? Rural nurses in Australia, 1991-1994. Collegian. 1997; $4(4): 22-7$

33. National Rural Health Alliance. Advanced nursing practice in rural and remote areas: position paper. 2005. http:// ruralhealth.org.au/sites/default/files/position-papers/positionpaper-05-07-01.pdf (accessed 14 Oct 2017)

34. Taylor SM, Usher K, McDermott R. Diabetes in Torres Strait Islanders: challenges and opportunities for remote area nurses. Contemp Nurse. 2013; 46(1): 46-53

35. Greene P, Burley M. The changing role of bush nurses in East Gippsland, Victoria. Rural Society. 2006; 16(1): 98-112.

36. Timmings RW. Rural and isolated practice registered nurse (RIPRN): emergency nurses of the Queensland 'bush'. Australas Emerg Nurs J. 2006; 9(1): 29-34.

37. Smith $T$, Jones P. Remote $x$-ray operator radiography: a case study in interprofessional rural clinical practice. $J$ Interprof Care. 2007; 21(3): 289-302.

38. Lenthall S, Smith J. Remote health practice. In: Smith J, editor. Australia's Rural, Remote and Indigenous Health. Chatswood: Elsevier; 2016; 285-315.

39. Whitehead L, Quinn R, Bryce J, Christian C, Fitzsimons J, Gascard D, et al. Position statement. Improving health outcomes in rural and remote Australia: optimising the contribution of nurses. Collegian. 2019; 26(3): 407-14. https:// doi.org/10.1016/j.colegn.2019.03.002 (accessed 13 Oct 2019).

40. Health Workforce Australia. Health workforce 2025: Doctors Nurses and Midwives - Volume 1. Adelaide (SA): Health Workforce Australia; 2012. https://apo.org.au/node/154456 (accessed 12 Jul 2018)

41. Burrows GL, Calleja P, Cooke M. What are the support needs of nurses providing emergency in rural settings as reported in the literature? A scoping review. Rural Remote Health. 2019; 19(2). https://www.rrh.org.au/journal/article/4805.doi:10.22605/ RRH4805 (accessed 13 Oct 2019) 